\title{
Overeducation and crowding out of low-skilled workers
}

Citation for published version (APA):

Muysken, J., \& ter Weel, B. J. (1998). Overeducation and crowding out of low-skilled workers. MERIT, Maastricht Economic Research Institute on Innovation and Technology. MERIT Research Memoranda No. $020 \mathrm{https}: / /$ doi.org/10.26481/umamer.1998020

Document status and date:

Published: 01/01/1998

DOI:

10.26481/umamer.1998020

Document Version:

Publisher's PDF, also known as Version of record

\section{Please check the document version of this publication:}

- A submitted manuscript is the version of the article upon submission and before peer-review. There can be important differences between the submitted version and the official published version of record.

People interested in the research are advised to contact the author for the final version of the publication, or visit the DOI to the publisher's website.

- The final author version and the galley proof are versions of the publication after peer review.

- The final published version features the final layout of the paper including the volume, issue and page numbers.

Link to publication

\footnotetext{
General rights rights.

- You may freely distribute the URL identifying the publication in the public portal. please follow below link for the End User Agreement:

www.umlib.nl/taverne-license

Take down policy

If you believe that this document breaches copyright please contact us at:

repository@maastrichtuniversity.nl

providing details and we will investigate your claim.
}

Copyright and moral rights for the publications made accessible in the public portal are retained by the authors and/or other copyright owners and it is a condition of accessing publications that users recognise and abide by the legal requirements associated with these

- Users may download and print one copy of any publication from the public portal for the purpose of private study or research.

- You may not further distribute the material or use it for any profit-making activity or commercial gain

If the publication is distributed under the terms of Article $25 \mathrm{fa}$ of the Dutch Copyright Act, indicated by the "Taverne" license above, 


\title{
Overeducation and Crowding Out of Low-Skilled Workers
}

\author{
J. Muysken ${ }^{\mathrm{a},{ }^{*}}$ and B.J. Ter Weel ${ }^{\mathrm{b}}$ \\ ${ }^{a}$ Department of Economics and MERIT, Maastricht University, P.O. Box 616, 6200 MD, Maastricht, the \\ Netherlands; Tel: 0031-43-3883821; E-mail: j.muysken@algec.unimaas.nl. \\ ${ }^{b}$ MERIT, Maastricht University, P.O. Box 616, 6200 MD, Maastricht, the Netherlands; \\ Tel: 0031-43-3883873; E-mail: b.terweel@merit.unimaas.nl.
}

\begin{abstract}
This paper develops a model to explain the following stylised facts: (1) returns to schooling have declined strongly over time and are only recovering gradually, whereas schooling attainment did recover much more strongly; (2) there is a rather general level of overeducation; (3) unemployment for low educated persons is much higher than for high educated persons; (4) the rate of return on overeducation is positive. In the model the search-theoretical analysis of Pissarides is applied to skilled demand for labour and extended to allow for job competition. It is combined with human capital theory to explain the level of education.
\end{abstract}

Keywords: overeducation, job competition, low skilled unemployment

JEL Classification:

* Corresponding author. 


\section{Introduction}

When Gottschalk (1997) discusses the increase in income inequality in the Nordic countries, the Netherlands, France and Japan in the late 1980's and early 1990's he observes that "the relatively small increase in inequality in the Netherlands reflects a decline in the college premium, which largely offsets the substantial increase in inequality between experience groups and the increase in inequality within groups." And this decline is due to "the large increase in the supply of college workers" while this "supply shift" is not further explained (pp. 34-35). He observes a similar phenomenon for Sweden.

The Swedish situation is presented by Topel (1997) who shows a sharp decrease in the college premium from the late sixties onwards, and again a small increase after the mid-eighties. Male school enrollment also drops sharply in the early seventies "which shows that college enrollments do respond to declining returns to schooling" (p. 69). However, Topel does not comment on the much stronger increase in school enrollment in the late eighties and early nineties, when compared to the very modest increase in the college premium. With respect to the latter he comments that "the returns to education in Sweden remain extraordinary low" (p. 70). Thus we observe the stylised fact that returns of schooling have declined strongly over time and are only recovering gradually, whereas schooling attainment if it declined at all, did recover much more strongly.

This observation is consistent with another stylised fact: there is a rather general level of overschooling, that is many persons are working on jobs that require less schooling than obtained. We illustrate this for the Netherlands in Table 1. From the table one sees that in particular in the lower segment of the labour market overschooling occurs to a large extent. ${ }^{1}$ One

\footnotetext{
${ }^{1}$ In 1996 Groot and Maassen van den Brink (1996) triggered a discussion on overeducation in the Netherlands. They state that overeducation did not increase between 1982 and 1995, based on two different data sets for the Netherlands. This point is criticised by Groeneveld (1996, p. 511), who points out that overschooling definitely may have increased when differences between these sets are corrected. However, an interesting observation of Groot and Maassen van den Brink is that overschooling is concentrated at part-time workers, workers with interrupted careers and beginning workers. Hence it is not necessarily crowding out low educated persons, but may be compensating lack of experience. Oosterbeek and Webbink (1996) also criticise the results reported by
} 
may wonder to what extent this is consistent with crowding out of low skilled workers by high skilled workers, ${ }^{2}$ but at least it indicates that high skilled school leavers find more easily a job than low skilled ones.

Table 1:

Percentage workers with excess education in the Netherlands

\begin{tabular}{|l|c|c|c|c|}
\hline Educational level of vacancies: & CBA & De Beer & \multicolumn{2}{|c|}{ CBS } \\
\hline & 1995 & 1996 & 1990 & 1995 \\
\hline Basic & 83 & 43 & 65 & 72 \\
\hline Lower (MAVO) & 31 & 32 & & 32 \\
\cline { 1 - 3 } Medium (LBO) & 16 & 11 & 36 \\
\hline
\end{tabular}

Source: CBA (1995), De Beer (1996), CBS (1995)

This is also observed in Gelderblom and De Koning (1994, pp. 40-41) who estimate age-activity profiles for men and women respectively, based on OSA-panel data for the Netherlands 1990. Their results show that the profile is higher, the higher the type of education - in particular in the case of women the difference is striking. The notion that high skilled school leavers find more easily a job than low skilled ones is also corroborated by the observation that the unemployment spell for school leavers decreases with educational level. And this is also reflected in the wellknown fact that the rate of unemployment decreases with the educational level - cf. Table 2 This is the third stylised fact we would like to present.

Groot and Maassen van den Brink. They use a different analysis in which returns on overeducation are calculated and compared to normal returns for men and women in the Netherlands, 1982 and 1995. Their results show a decline for men in returns of overschooling, but for women the opposite holds.

${ }^{2}$ Gelderblom cs. (1997) observe that education may be related to opportunity to find a job, which in its turn may lead to crowding out of low educated persons. Van Ours and de Ridder (1995) find that no crowding out did occur in the Netherlands, but their results have been criticised by De Beer (1996) because Van Ours and Ridder assume that low and high educated persons have the same probability to be accepted on a low skilled job. 
Table 2:

Education and unemployment in 1990

\begin{tabular}{|l|l|c|}
\hline \multicolumn{2}{|l|}{ Level of education } & Unemployment (\%) \\
\hline Basic & $B O$ & 15 \\
Low & VBO & 7 \\
Medium & $M B O$ & 4 \\
High & HBO/WO & 4 \\
\hline Total & & 6 \\
\hline
\end{tabular}

Source: CBS, Enquête Beroepsbevolking (1995)

Finally, Table 3 illustrates the widely observed phenomenon that rate of return to overeducation $(\mathrm{O})$ is lower than the rate of return on required education, but positive. ${ }^{3}$ And this constitutes our fourth stylised fact.

Table 3:

Returns to human capital in the Netherlands

\begin{tabular}{|l|r|r|r|}
\hline Studies & O & \multicolumn{1}{|c|}{$\mathrm{R}$} & \multicolumn{1}{c|}{$\mathrm{U}$} \\
\hline Hartog and Oosterbeek (1988) & 0.057 & 0.071 & -0.025 \\
Sicherman (1991) & 0.039 & 0.048 & -0.017 \\
Van Smoorenburg and Van der Velden (1995) & 0.027 &.. & -0.022 \\
Cohn and Khan (1995) & 0.049 & 0.077 & -0.038 \\
Sloane, Battu and Seaman (1995) & 0.028 & 0.178 & -0.034 \\
Oosterbeek and Webbink (1996) (males) & 0.052 & 0.092 & -0.033 \\
Groot (1997) & 0.028 & 0.061 & -0.026 \\
\hline
\end{tabular}

O- overeducation, $\mathrm{R}$ - required education, $\mathrm{U}$ - undereducation

Source: Van Eijs and Heijke (1996) and Hartog (1997)

Together these stylised facts suggest that nowadays the decision to schooling is no longer

\footnotetext{
${ }^{3}$ For a survey of the empirical findings with respect to overeducation see Hartog (1997).

${ }^{4}$ Van Smoorenburg and Van der Velden (1995) used education required as a reference point.
} 
primarily influenced by future wages, but by the possibility to get a proper job. ${ }^{5}$ Thus the relevant characteristic of the job which determines schooling is not primarily the level of education required and its corresponding wage, but the probability of obtaining that job at all - although the corresponding wage level may be relatively low. This notion is consistent with the sorting hypothesis and the related labour queue theory. ${ }^{6}$ For employers typically use education as a screening device for unobserved characteristics like ability to learn, and a low quit rate. And workers therefore use this as a device to signal their unobservable characteristics.

According to human capital theory, productivity, and hence wages, are not influenced by job characteristics but by individual endowments; this implies that the wage rate is merely determined by the supply side. Estimating wage functions and explaining differences in these wages are important issues in human capital theory. Ability, education and training are the determinants of the amount of human capital an individual embodies and, as a result, of an individual's productivity on the job. ${ }^{7}$ Embedded in a neoclassical framework, human capital theory implies that a higher ability and more education do not only result in a higher level of productivity but also leads to a higher wage rate. This wage rate varies with in the absolute amount of human capital an individual embodies. This feature of human capital theory is criticized in Thurow (1975). In his job competition model productivity and wages are tied to jobs instead to persons. Workers are ranked in a so-called labour queue based on their training cost. This means that high skilled workers are ranked higher than low skilled workers, because the former group is more easily to train than the latter, i.e. the relative educational level determines the individual's employment chance.

While human capital theory focuses on the supply side of the labour market and job competition

\footnotetext{
${ }^{5}$ To a certain extent this is corroborated by Webbink (1996) who uses survey data for 1990 and 1995 to determine the extent to which the choice for a certain type of education is motivated by labour market perspectives. He finds that labour market perspectives definitely do matter. However, people often use stereotypes of labour market chances in this context. And an interesting observation is that the 1995 generation is more fixed on labour market perspectives than the 1990 generation.

${ }^{6}$ An interesting overview of sorting theory as opposed to human capital theory is given in Weiss (1995). The labour queue theory is developed in Thurow (1979).

${ }^{7}$ See, e.g. Schultz (1961) and Becker (1962) for the initial approaches of human capital theory.
} 
models focus on the demand side, matching theory concentrates on both. On the one hand, the demand side of the labour market is assumed to consist of jobs with different skill requirements. On the other hand, the supply side consists of individuals that have acquired skills by means of education. ${ }^{8}$ Pissarides (1990), Layard, Nickell and Jackman (1991) and Phelps (1994) build a model that treats both sides of the labour market. However, the combination between job competition models, human capital theory and matching theory is never explicitly stated.

Starting from a matching function we build a model that captures all ingredients of both human capital theory and labour queue theory. ${ }^{9}$ We show that the adjustment mechanism in the economy is determined on the one hand via wages but on the other hand through the number of jobs supplied by employers, given the level of skills. Next to that we are able to show that the wage level is rather stable despite the major absolute increase in the level of education. Here human capital theory would predict an enormous rise in wages, whereas labour queue theory defines a stable wage level in accordance with a stable supply of the relative skill level. ${ }^{10}$

In order to explain the four stylised facts, we are interested in a more precise analysis of the interaction of schooling decision, duration of unemployment and wages. A framework for such an analysis is presented in this paper. We proceed in the following way. First, we build a model on matching, ability and years of schooling which serves as our general framework for the remainder of the paper. Then, we extend this model in section 3 to show the impact and implications of different levels of skills for our analysis. In section 4 we explain and show some evidence with respect to the stylised facts stated in the introduction. We end with some concluding remarks.

\footnotetext{
${ }^{8}$ In this paper we only make a distinction between skilled $\left(L_{s}\right)$ and unskilled $\left(L_{u}\right)$ labour. For a more elaborate model on skills see, e.g. Van Zon, Muysken and Meijers (1998) and Hollanders and Ter Weel (1998).

${ }^{9}$ Groot and Hoek (1997) illustrate the working of the labour market under the assumptions of human capital and labour queue theory. They stress the differences between both theories.

${ }^{10}$ In this context Kettunen (1994) also uses a different argument from sorting: a higher educated person can perform a job at a lower level, but a low educated person cannot perform a job at a higher level.
} 


\section{Matching, Ability and Years of Schooling}

\section{The General Structure}

The labour market consists of two sectors. One sector requires skilled labour - which has a level of skills $s$ of at least a given level $\hat{s}$ - whereas the other sector requires only unskilled labour. Supply of skilled labour can be increased by means of schooling. We assume the wage rate for unskilled labour to be fixed at the level $w_{u}$, which is above the unemployment benefit. Moreover, employers will prefer skilled labour to unskilled labour to perform unskilled jobs at the wage rate $w_{u}$. Hence we assume unemployment, if any, to be concentrated to unskilled workers. Skilled workers working in the unskilled sector are called underemployed.

In the analysis we will focus on the skilled sector. Since employers are looking for skilled labour, we first analyse the matching process resulting from the search for skilled workers. This shows how underemployment duration is related to labour-market tightness. The latter is ultimately determined by the wage formation process for skilled labour. Therefore we elaborate how given the level of skills required, $\hat{s}$, the wage is determined in a bargaining process between workers and firms. Given both underemployment duration and wage we next analyse how many years a worker wants to school himself in order to obtain that required skill $\hat{s}$. This finally defines supply of skilled labour and underemployment in the skilled sector.

\section{The Matching Process}

Employers in the skilled sector require skilled labour and hence will search for that type of labour, whereas skilled workers prefer to work in the skilled sector since it will pay a higher wage. To make this more explicit we introduce the matching process in the analysis. ${ }^{11}$

\footnotetext{
${ }^{11}$ To large extent we will follow the analysis as developed in Pissarides (1990), chapter 1.
} 
Using the concept of a matching function, the rate at which a vacant job becomes filled, $\mathrm{m} / \mathrm{v}$, is determined by

$$
\frac{m}{v}=q(\theta) \quad q_{\theta}, q_{\theta \theta}<0
$$

where $q$ represents the matching function and $\theta=v / u$ represents labour-market tightness $-m, v$ and $u$ are the rate of matches, vacancies and unemployment, respectively. ${ }^{12}$

In this context $v$ represents vacancies for skilled workers and $u$ actually is underemployment of skilled labour. That is, $u$ refers to skilled workers working in the unskilled sector, they have invested in schooling but are not able to obtain work in the skilled sector. The mean duration then refers to the time they are working in the unskilled sector at a wage $w_{u}$. To that end we introduce a waiting period $d$ between the end of schooling $j$ and the start of working in a proper i.e. skilled - job. During that period, which can be interpreted as the period of searching for a proper job, one can earn the unskilled wage $w_{u}$. By definition the mean duration of underemployment, or search duration, equals

$$
d(\theta)=\frac{1}{[\theta . q(\theta)]} \quad d_{\theta}<0
$$

A final observation is that the model can be used to determine equilibrium underemployment, $u^{*}$. In the steady state this is equal to

$$
u^{*}=\frac{x}{\left[x+\frac{1}{d(\theta)}\right]} \quad u_{\theta}<0
$$

where $x$ is defined as the flow into underemployment, relative to employment, resulting from e.g.

\footnotetext{
${ }^{12}$ We assume the matching function to be linear and homogenous in unemployment and vacancies. Pissarides (1979), Blanchard and Diamond (1990), Layard, Nickell and Jackman (1991), Van Ours (1991) and Romer (1996) show that constant returns to scale is a satisfactory approximation to reflect the matching process and to adopt an appropriate matching function.
} 
structural shifts in the demand for labour. As one might expect, equilibrium underemployment will follow search duration $d$ closely.

\section{Wage Formation and Underemployment}

Let production in the sector with skilled labour exhibit constant returns to scale in capital and labour. Labour is assumed to have a level of skills of at least $\hat{s}$, determined by the employers on beforehand. Then the production structure is represented by the production function

$$
y=f(k) \quad f_{k}>0, f_{k k}<0
$$

where $y$ represents output per worker, $k$ represents the capital stock per worker and $s$ is defined as the skill level per worker. The production function is assumed to be well-behaved and given the interest rate, $r$, the capital stock $k$, is determined by

$$
f_{k}=r+\delta
$$

where $\delta$ is defined as the rate of depreciation. Thus, from equation (5) we observe that the marginal product of capital is equal to the marginal cost of capital, i.e. the interest rate plus the depreciation rate. Finally, if equation (5) is satisfied, the marginal product of labour $\hat{g}$ is given by:

$$
\hat{g}=f(k)-(r+\delta) k
$$

When looking at the demand for skilled labour by the firm, we should also take the search process into account. Essential in the analysis of Pissarides is the notion that an open vacancy represents search and hiring cost to the firm of $\gamma_{0}$ per period of time. As a consequence the expected capitalised value of the firms hiring cost enters the demand function for labour, next to the marginal product of labour. That is, in the demand function for labour the usual marginal productivity condition is amended as follows: 


$$
\hat{w}_{s}=\hat{g}-\frac{(r+x) \gamma_{0}}{q(\theta)}
$$

In this equation $\hat{g}$ is the marginal product of labour and the last term of the right-hand side is the expected capitalised value of the firm's hiring cost. It varies positively with the interest rate and the rate of outflow of employment into unemployment, and negatively with the matching rate. Equation (7) shows a negative trade-off between labour-market tightness and wages employers are willing to offer. The reason is that when labour-market tightness increases, this will decrease the probability to find a good match and hence increase the capitalised value of the firm's hiring cost. In order to compensate for these cost the firm will then be willing to offer a lower wage.

Wages are determined by a Nash-bargaining process, in which the bargaining power of workers and employers are represented by $\beta$ and $1-\beta$, respectively, with $0<\beta<1$. The resulting wage can be represented by

$$
w_{s}^{*}=(1-\beta) w_{u}+\beta\left(\hat{g}+\theta \gamma_{0}\right)
$$

where $w_{u}$ is the worker's fall back position - i.e. working in the unskilled sector. Since $\theta \gamma_{0}$ is the average hiring cost for each new worker, it is intuitively clear that they are added to the marginal product of labour. ${ }^{13}$ This also explains why the bargained wage is an increasing function of labour-market tightness, $\theta$ - cf. the bargained real wage (BRW) curve in Figure 1.

The equilibrium wage then is determined by $\hat{W}_{s}=w_{s}{ }^{*}$. Hence we find the wage for skilled labour as a premium on the wage of unskilled labour:

$$
w_{e}=w_{u}+\frac{\gamma_{0} \cdot \beta}{1-\beta}\left(\theta_{e}+\frac{r+x}{q\left(\theta_{e}\right)}\right)
$$

\footnotetext{
${ }^{13}$ As Pissarides (1990), p. 12 states:"Workers are rewarded for the saving of hiring cost that the firm enjoys when a job is formed." Burdett and Smith (1996) choose a different route by emphasising that the outside option for firms increases when more workers are available.
} 
where $\theta_{e}$ is the equilibrium level of labour-market tightness. As one might expect the premium is increasing when the bargaining power of workers and the search and hiring cost increase.

This equilibrium is illustrated in Figure 1. It is obvious that equation (8) - the BRW-curve - is a straight line, increasing in labour-market tightness $\theta$ with slope $\beta \gamma_{0}$. Equation (7) - the demand for labour - on the other hand is decreasing in labour-market tightness: the higher the elasticity of the matching function is with respect to $\theta$ in absolute terms, the stronger the function will be sloping downward. The intersection between both lines defines $\theta_{e}$ and $w_{e \cdot 14}$ The lower half of Figure 1 shows the inverse relationship between duration and labour-market tightness - cf. equation (2). Thus the equilibrium labour-market tightness $\theta_{e}$ determines search duration $d_{e}$. And the equilibrium rate of underemployment is determined by substituting $d_{e}$ in equation (3).

\section{Supply of Skills and Schooling}

With respect to supply of labour we assume an ability distribution over the labour force $N$. More specific, we assume that abilities $a$ are distributed uniformly over the range [0, A]. However, although abilities imply a certain amount of skills, the skills can be improved by schooling. ${ }^{15}$

Therefore, we define the level of skills $s$ as a positive function of ability $a$ and years of education j. A convenient expression is:

$$
s=a \cdot e^{\alpha j} \quad \alpha>0
$$

Thus workers with an ability below the level of skills required in the skilled sector, $\hat{s}$, can try to obtain work in that sector by schooling themselves. The parameter $\alpha$ indicates the productivity of schooling - the higher $\alpha$, the more productive is schooling.

\footnotetext{
${ }^{14} \theta_{e}$ is implicitly defined by the equality of the right hand sides of equations (7) and (8).

${ }^{15}$ For simplicity we assume $A<\hat{s}$, hence anybody will follow some schooling.
} 
Figure $1^{16}$

Determining the Relation between Labour-Market Tightness, Wage and Duration

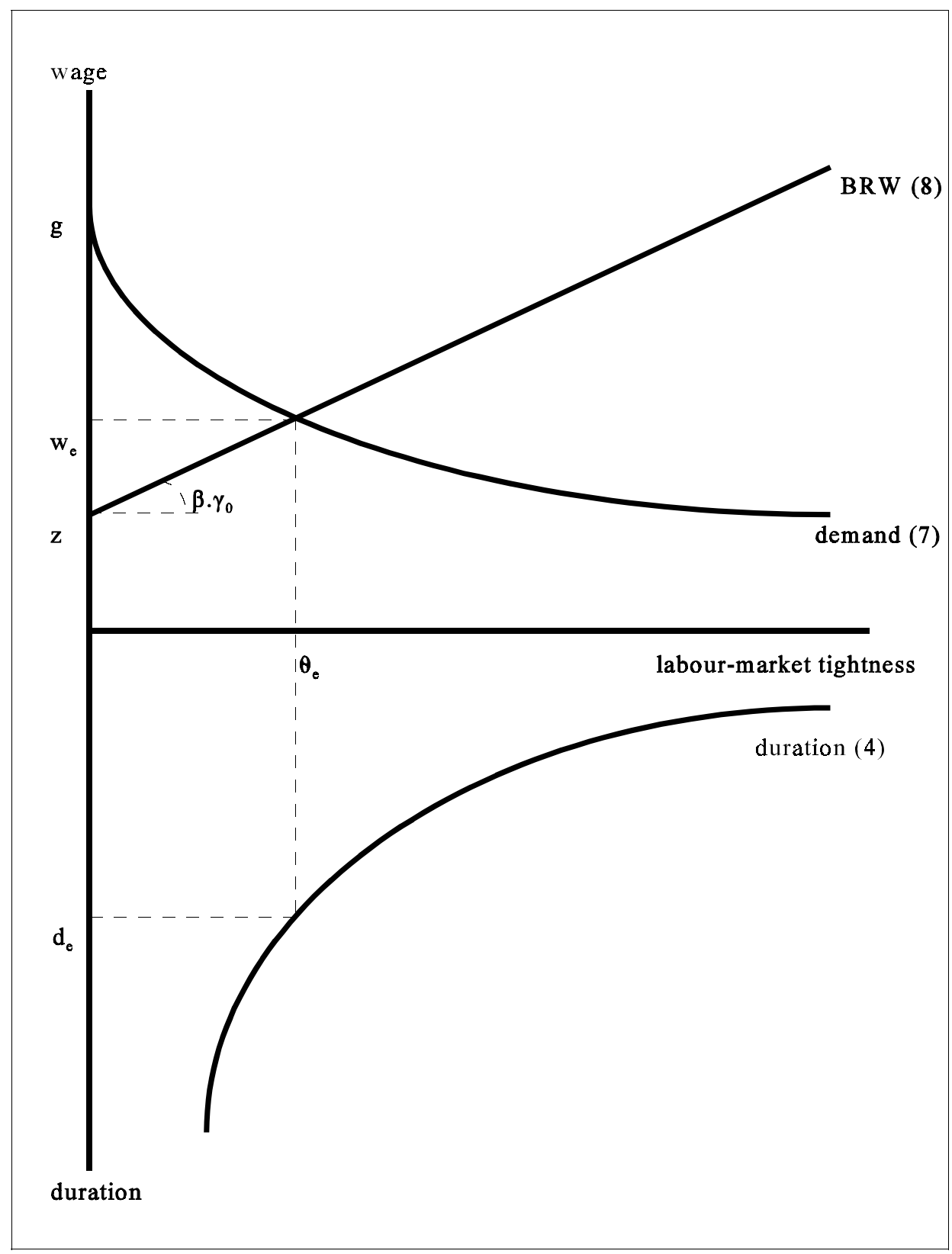

Given the level of skills demanded, $\hat{s}$, one sees from equation (10) that the marginal ability $\hat{a}$ at which a worker qualifies for skilled labour decreases with the number of years of schooling. Thus

\footnotetext{
${ }^{16}$ Note: $\mathrm{z}$ is equal to $(1-\beta) w_{u}+\beta g$.
} 
supply of skilled labour is determined by the years of schooling in the following way:

$$
\frac{L^{s}}{N}=\int_{\hat{a}(j)}^{A} d a=1-\frac{\hat{s} \cdot e^{-\alpha j}}{A}
$$

It is obvious that supply of skilled employment increases with years of schooling. The remaining part of the labour force, with ability below $\hat{a}$, constitutes unskilled labour supply.

With respect to the determination of years of schooling, we follow the tradition of human capital theory. Therefore we assume that schooling is an investment decision, with regard to the years of education, that pays off by means of a higher wage. While unskilled work pays a wage $w_{u}$, it is expected that a higher educational level will earn a higher wage $w_{s}$. From human capital theory we know that the individual with a marginal ability will obtain education for $j$ years such that

$$
\int_{0}^{\infty} w_{u} e^{-r t} d t=-\int_{0}^{j}\left(c+w_{u}\right) e^{-r t} d t+\int_{j}^{\infty} w_{s} e^{-r t} d t
$$

holds. In this equation $r$ represents the rate of interest and $c$ corresponds to the real cost of schooling per year (minus any direct utility from schooling).

However, due to the introduction of the search process, we have to adapt the above representation of human capital theory to explain this phenomenon. Since skilled workers expect a search duration $d_{e}$ as determined in Figure 1, they expect to earn $w_{u}$ during $d_{e}$ periods, before earning the skilled wage $w_{e}$. Therefore, we elaborate equation (12) in the following manner:

$$
\int_{0}^{\infty} w_{u} e^{-r t} d t=-\int_{0}^{j}\left(c+w_{u}\right) e^{-r t} d t+\int_{j}^{j+d_{e}} w_{u} e^{-r t} d t+\int_{j+d_{e}}^{\infty} w_{e} e^{-r t} d t
$$


where $w_{e}$ and $d_{e}$ are defined by the analysis in Figure $1 .{ }^{17}$ Solving equation (13), yields

$$
w_{e}=e^{r d_{e}}\left[e^{r j}-1\right]\left(2 w_{u}+c\right)+w_{u}
$$

Equation (14) gives an implicit solution $j_{e}$ of years of schooling of the individual with a marginal ability, such that the required skill level $\hat{s}$ is reached. Substituting $j_{e}$ in equation (11) then determines supply of skilled labour.

It should be emphasised that equation (14) refers to the individual with the marginal ability. For others with a higher ability will obtain less schooling. Actually, individuals in the range $[\hat{a}, A]$ will follow precisely sufficient years of schooling to obtain skill $\hat{s}$. This follows immediately from the insight that the right-hand side of equation (13), which represents the total returns from schooling, is decreasing in the number of years of schooling.

From equation (14) one sees that the marginal individual's decision to obtain education depends positively on the wage this person can earn after schooling, $w_{e}$, and negatively on forgone income $w_{u}$, search duration $d_{e}$, and the cost of education $c$. However, it is remarkable that in the analysis the level of skills required has no impact on schooling whatsoever. We will return to this point below.

\section{Equilibrium on the Skilled Labour Market}

Thus far we have determined the wage rate $w_{e}$ and supply of labour $L^{S}$, but demand for labour still has not been discussed. Actually it is implicit in the analysis, and to point that out enhances our understanding of the nature of the equilibrium of the labour market.

As is obvious from the above analysis, equilibrium is determined through the process of wage

\footnotetext{
${ }^{17}$ We assume that the expectations will always be realised.
} 
formation. Given the level of skills required, the equilibrium wage $w_{e}$ is determined in a bargaining process. This implies that a certain labour-market tightness $\theta_{e}$ and a corresponding search duration $d_{e}$ are necessary to ensure that the bargained real wage - cf. equation (8) - equals the real wage employers are willing to offer - cf. equation (7). As a consequence the equilibrium rate of underemployment is determined by substituting $d_{e}$ in equation (3). This implies that employers will demand labour consistent with that rate, given a certain supply of labour. Hence demand for labour $L^{D}$ will equal:

$$
L^{D}=\frac{1}{1+x \cdot d_{e}} \cdot L^{S}
$$

where $L^{S}$ follows from substituting $j_{e}$ - cf. equation (14) - in equation (11). 


\section{The Impact of Skills}

\section{The Matching Process}

In the above model employers in the skilled sector search for skilled labour at a given level of skills. However, we ignored the fact that schooling has a positive impact on the matching process since more job opportunities arrive when the level of education is higher. ${ }^{18}$ For a higher educated person can perform a job at a lower level, but a lower educated person cannot perform a job at a higher level, an employer will prefer to hire a person with a higher level of education for a lower skilled job at the same wage he would pay a lower skilled worker for at least two reasons. ${ }^{19}$ First, the worker may turn out to be more productive than a lower skilled worker - which will be compensated by a higher wage to an extent depending on the bargaining power of both parties. Second the lower skilled job provides a good opportunity to observe and monitor the qualities of the worker, before he might be offered a higher skilled job. This argument is consistent with the screening hypothesis and the job queue theory mentioned in the introduction. Screening theory underscores information generated on individuals by education. The general idea is that higher educated and, therefore, highly skilled individuals are more productive than less educated and skilled individuals. Spence (1973) describes this process as follows. An applicant knows his productivity and skills when he applies for a job. However, the employer observes both exogenous indices like e.g. race, age and gender and endogenous signals given by the applicant like e.g. education and commitment to influence his choice. The employer uses these both the exogenous and endogenous variables to estimate the applicant's productivity, i.e. he computes a kind of inference rule. Now, an equilibrium is obtained when the applicants's signals given the inference rule and the inference rule itself are correct. Since information is imperfect, a potential employee's productivity cannot be recognised on beforehand and hence employing a worker at

\footnotetext{
${ }^{18}$ Burdett and Smith (1996) use a somewhat related model to study the relation between matching and education - although they emphasise the bargaining process between (un)skilled workers and firms and pay no explicit attention to the duration of search.

${ }^{19}$ This argument is also used by Kettunen (1994). However, he assumes that the matching probability will decrease again at higher levels of education, since he assumes that both the lump-sum costs and the variable costs of accepting another job also increase with education.
} 
first on a low-skilled job is a good opportunity for the employer to monitor his newly hired employee. The related labour queue theory assumes that specific skills are required which have to be acquired by on-the-job training. However, firm specific training involves costs. Since, welleducated individuals are more easily to train, and the costs involved are therefore lower, these individuals are in front of the labour queue. In Thurow's words: "Education and training have to great extent been based on a 'wage competition' view of the labour market. They have not had the predicted impact since they have ignored 'job competition' elements in the labour market." (Thurow, 1979, pp. 17-18). Instead of competing against each other based on wages, individuals compete for jobs based on background characteristics.

When we integrate the notions of screening and labour queue theory in the matching function, we assume that the level of skills required by the employers is $\hat{s}$, i.e. their inference rule states that they have to employ workers with skills of at least $\hat{s}$. Then the rate, $m / v$, at which a vacant job of skill level $\hat{s}$ becomes filled by a person with skill $s$ is determined by:

$$
\frac{m}{v}=q(\theta, s / \hat{s}) \quad q_{s}>0, q_{\theta}, q_{\theta \theta}<0, s \geq \hat{s}
$$

From the discussion above it follows that the probability of finding a match is increasing in the level of skills $s$. This might provide an incentive to individuals to obtain a skill which is higher than $\hat{s}$.

It is obvious that the search period is negatively related to the level of skills since the higher the skill, the easier it is to find a job. Thus we have:

$$
d(\theta, s / \hat{s})=\frac{1}{[\theta . q(\theta, s / \hat{s})]} \quad d_{s}, d_{\theta}<0
$$

Finally, equilibrium underemployment is defined analogous to equation (3):

$$
u(\theta, s / \hat{s})=\frac{x}{x+\frac{1}{d(\theta, s / \hat{s})}}
$$


Both equilibrium underemployment and average search duration will decrease in $s$, the level of skills obtained. We will now analyse how this level is determined. But first some brief comments on wage formation.

\section{Wage Formation}

With respect to wage formation, we essentially follow the analysis from the previous section. The skill required by employers is $\hat{S}$, which is determined primarily by technology. Moreover, the employers evaluate their hiring costs at a search effort consistent with $q(\theta, 1)$, in stead of consistent with the search duration of equation (17) with the skill level that is actually chosen. The reason is that skill competition does not necessitate the employers to pass on the rents from lower hiring costs to skilled workers.

The outcome then is again as in the upper half of Figure 1: an equilibrium wage and labourmarket tightness, $w_{e}$ and $\theta_{e}$, respectively. From the above analysis it is obvious, however, that search duration and equilibrium underemployment are determined in a way different from the lower half of Figure 1. We will elaborate this further below.

\section{Supply of Skills}

With respect to the supply of skills, it can be shown that the total benefits of schooling are increasing in the level of skills obtained, provided that the impact of skills on search duration is sufficiently large. We assume this to be the case. ${ }^{20}$ Hence given the level of skills set by the

\footnotetext{
${ }^{20} \mathrm{We}$ assume that the elasticity of matching with respect to schooling at $\hat{s}$ to be sufficiently large:

$$
\frac{1}{q} \cdot q_{s}>\frac{1}{\alpha \cdot d_{e}} \cdot \frac{e_{r j_{e}}}{e^{r j_{e}}-1}
$$
}

where $j_{e}$ is defined in equation (14) and $d_{e}$ follows from Figure 1. 
entrepreneurs $\hat{S}$, there is always a potential for higher skills. This is also consistent with the notion mentioned above that skill competition does not necessitate the employers to pass on the rents from lower hiring costs to skilled workers.

For each ability, the optimal level of skills $s^{*}$ can be obtained from maximising the total benefits of schooling with respect to skills - cf. the right-hand side of equation (13) with endogenous duration $d_{e}$. This yields:

$$
-\alpha \cdot s^{*} \cdot d_{s}\left[\theta_{e}, \frac{s^{*}}{\hat{s}}\right]=1+\frac{2 w_{u}+c}{\left[w_{e}-w_{u}\right] \cdot e^{-r \cdot d\left[\theta_{e}, \frac{s^{*}}{\hat{s}}\right]}}
$$

The optimal level is such that the impact of skills on search duration exactly balances the cost of schooling. It is interesting to note that the optimal level of skills $s^{*}$ is independent of the ability: any individual who adopts schooling will obtain the level $s^{*}$. As a consequence the higher the ability of an individual is, the lower his or her optimal years of schooling are. And this implies that total returns to schooling, ie life-time income, increase with ability. Therefore the rate of return to schooling increases with ability too.

Given $s^{*}$, the analysis of the previous section still holds for the marginal ability. Hence the years of schooling $j^{*}$ are determined analogous to equation (13):

$$
w_{e}=e^{r \cdot d\left(\theta_{e}, \frac{s^{*}}{\hat{s}}\right)}\left[e^{r . j *}-1\right]\left(2 w_{u}+c\right)+w_{u}
$$

Since $d\left[\theta_{e}, s^{*} / \hat{s}\right]<d\left[\theta_{e}, 1\right]$, the years of schooling $j^{*}$ of the marginal individual exceed those found in the analysis of the previous section, $j^{e}$ - compare equation (14). In order to enhance the possibility to find a skilled job, the marginal individual will have more years of schooling.

The marginal ability $a^{*}$ will be determined by: 


$$
a^{*}=s^{*} \cdot e^{-\alpha \cdot j *} \quad \alpha>0
$$

Since both $j^{e}<j^{*}$ and $\hat{s}<s^{*}$, the impact on the marginal ability has opposite effects. However, it can be shown that these effects neutralise each other such that the marginal ability $a *$ is exactly equal to the marginal ability $\hat{a}$ found in the previous section - cf. equation (11). This implies that supply of labour is equal to that of the analysis in the previous section in terms of number of persons. However, the level of skills is higher.

\section{Equilibrium and overeducation}

Since the level of skills is higher, search duration is lower and therefore equilibrium underemployment is lower as can be seen from equation (18). We then know from equation (15) that demand for skilled labour will be higher. The reason for a higher demand for labour lies in the lower hirings costs than expected. Employers evaluate the expected hiring costs at a skill $\hat{s}$, whereas the skills turn out to be higher at a level $s *{ }^{21}$ As a consequence the matching process is improved and hiring costs are lower. ${ }^{22}$ At the same wage then more persons will be hired.

When we compare this situation with the situation in the previous section, where the impact of skills on the matching process is ignored, the following observations can be made. The level of skills demanded by employers and the wage rate for skilled labour have not changed. The same number of persons will offer skilled labour. However, the level of skills offered $s *$ is higher and lies above the level of skills $\hat{s}$ demanded. In that sense overeducation is a general phenomenon for skilled labour. Since wages have not increased, this implies lower returns to schooling, while

\footnotetext{
${ }^{21}$ One might argue that this is inconsistent with rational expectations. However, in this case the employers state their wages in the context of a wage bargaining process. Their claim will be that they demand a wage consistent with a level of skills $\hat{\boldsymbol{s}}$. And it is in their interest to keep the wage as low as possible since when they later demand more persons because the hiring costs turn out to be lower, the resulting profits will be higher.

${ }^{22}$ A similar argument is found in Groot and Hoek (1997) who argue the decline in search and hiring costs can be explained from labour queue theory. For in a slack labour market, as is currently experienced in the Netherlands, labour queues are longer than job queues. In these relatively long labour queues workers at the end of the queue remain unemployed. Now, a rise in the level of education in a slack labour market, does not lead to a higher wage but to lower hiring cost on the side of employers because they face a better educated and therefore more easy to employ workforce.
} 
schooling attainment has increased. Moreover, the rate of return to overschooling is positive for all persons with a skill higher than the marginal skill. This follows from the observation made above that the total returns to schooling increase with ability.

On the other hand, the rate of underemployment is lower. Hence less skilled persons will be working in the low-skilled sector. And therefore also less crowding out will take place. ${ }^{23}$

These observations show already that it can be used to explain the stylised facts which we have discussed in the introduction of our paper. However, for a proper discussion, we have to analyse evolution of the labour market in the course of time. This is the subject of the next section.

\footnotetext{
${ }^{23}$ In that sense overschooling can be said to cause the chimney-effects as discussed in Van Zon, Muysken and Meijers (1998).
} 


\section{The Stylised Facts Explained}

It seems reasonable to argue that several of the variables which are exogenous to our analysis have changed in the course of time and therefore had an impact on overeducation and underemployment as can be explained from the analysis in the previous section. The resulting picture then is consistent with the stylised facts as we shall show below.

\section{Changes over Time in Exogenous Variables}

We first look at the process of wage formation as depicted in the upper half of Figure 1. The slope of the wage offered by employers - cf. equation (7) - is equal to $-(r+x) \cdot \gamma_{0} \cdot \varepsilon(q, \theta) / q$, where $\varepsilon(q, \theta)$ is the absolute value of the elasticity of matching with respect to labour-market tightness. The slope of the bargained wage - cf. equation (8) - is equal to $\beta \gamma_{0}$. Hence the higher the hiring costs are and the stronger the bargaining power of workers is, the steeper equation (8) will be. Moreover, higher hiring costs also imply a stronger slope of equation (7). The same holds for a higher of interest and a higher rate of turnover.

Actually, in the early seventies most of these variables have increased. ${ }^{24}$ Moreover, the UV-curve shifted outwards, indicating a deterioration of the matching process. ${ }^{25}$ This also had an impact on the slope of equation (7). ${ }^{26}$ The resulting shifts are shown in Figure 2, which shows how a higher wage resulted, together with a slacker labour market - cf. the increase from $w_{1}$ to $w_{2}$ and the decrease from $\theta_{1}$ to $\theta_{2}$, respectively. The consequences of this process for un(der)employment can be derived from the lower half of Figure 2, through the impact on duration. While the slacker labour market already implies an increase in duration of unemployment, the impact was worsened by the outward shift in the duration curve due to the worsening of the matching

\footnotetext{
${ }^{24}$ See various papers in Muysken and De Neubourg (1989).

${ }^{25}$ An overview is presented in Muysken (1989).

${ }^{26}$ The same holds for the impact of the demand shock resulting from the oil crises.
} 
process.

Many of these tendencies have been reversed in the eighties and nineties. Although no hard figures are available, it seems highly plausible that the power of the unions $\beta$ and the search and hiring costs $\gamma_{0}$ have declined, when compared to the early seventies. For instance, in the Netherlands the percentage union members among the working labour force fell from $38 \%$ in 1975 to $25 \%$ in $1996 .{ }^{27}$ In addition, since the early 1980 s wage moderation has been an important component of labour-market policy. ${ }^{28}$

The decline in search and hiring costs can be explained by the increase in part-time working. The OECD (1998, pp. 160-166) argues that even when schedules in a firm are fixed within the working day, part-time employment may add to flexibility if it can be arranged to coincide with peaks in labour requirements. In establishment surveys in some European countries, the majority of managers said that the primary reason for the introduction of part-time working was to meet the needs of the firm. In such circumstances, managers favoured shorter hours ( $<20$ a week), and mainly saw a need for low-skilled part-time workers. Moreover, for the European Union, calculations from the European Union Labour Force Survey show that one-third of all part-time workers are employed during evenings, nights and weekends. Particularly and most importantly, part-time workers are very unlikely to attract overtime premiums and may well be cheaper than the same hours worked by full-time workers. Finally, it should be noted that the extent of parttime employment is very large in the Netherlands. In 1996 the part-time employment as a percentage of total employment was $36.5 \%$ whereas it was only $16.6 \%$ in 1979 . By contrast, Austria, Belgium, Finland, France, Portugal and Spain do not even reach the Dutch 1979-level in 1996, while Sweden and Switzerland are numbers two and three with only $23.6 \%$ and $27.4 \%$

\footnotetext{
${ }^{27}$ Van der Geest (1995) gives four reasons for the decline in the Netherlands. In the first place he notes that large industrial firms with a lot of unskilled workers have disappeared. This is attended by a decline in union membership. Secondly, a change in the composition of the labour force from un- and low-skilled male workers to a well-educated workforce with many women and part time workers involved has led to a decline in union membership. Thirdly, cultural changes like individuality accompanied an adverse shock to union membership. Finally Van der Geest argues that due to decentralised wage bargaining the unions lost bargaining power.

${ }^{28}$ See for recent studies in the Netherlands Lever (1995), Van Lede (1995) and Koeman (1996). Kleinknecht (1996) counter argues with respect to the success of wage moderation that employment growth is only observed because of a lack in labour productivity relative to other OECD countries.
} 
part-time workers - cf. OECD (1998).

These trends will lead to a reversion of the process in the seventies as depicted in the upper half of Figure 2. Wages have a tendency to decrease from $w_{2}$ towards $w_{1}$ and labour-market tightness will increase from $\theta_{2}$ to $\theta_{1}$.

From the point of view of our analysis also an important change did occur in the matching process. It seems plausible that the impact of schooling on matching has increased strongly. Such an effect has been underlined by, amongst others, Howell and Wolff (1992) for the US and by Goux and Maurin (1995) for France. These authors argue that the increased demand for skilled labour could be stimulated by slacks in labour markets which induce longer stays in initial formal education to delay entry into the labour market and by individuals trying to improve their chances of finding employment. In their view the increased demand for education therefore certainly is a part of the explanation for increasing average levels of education and the number of years of education attended as apparent in all OECD countries.

The observation that increased demand for schooling may result from a slack labour market is consistent with our analysis, since a change in labour-market tightness will affect the optimal level of skills and hence schooling. From equation (19) it can be derived that under plausible assumptions a slack labour market will correspond to a higher level of skills, i.e. $\mathrm{d} s * / \mathrm{d} \theta<0 .{ }^{29}$ This is also intuitively clear since in a slack labour market the matching probability is lower and hence there is a higher need for additional schooling.

However, it also seems plausible that the elasticity of matching with respect to schooling has increased. Employers are believed to be more focussed on skills nowadays than they were in the early seventies. One of the reasons is a rachet effect: once a level of skills is provided above the level demanded by the employers, the employers will automatically adapt to that level and hence demand higher skills than they originally intended to do. Another reason is the larger availability of schooling opportunities in general. Amongst others these reasons imply an inward shift of the

\footnotetext{
${ }^{29}$ Sufficient conditions are that for duration $d_{s \theta}, d_{s s}<0$ does hold, and the right-hand side of equation (19) exceeds $1+\alpha$.
} 
duration curve as represented in the lower half of Figure 2, because matching improves given labour-market tightness. As a consequence the tendencies in the late eighties and nineties which lead to a tighter labour market, as we have indicated above, will not automatically lead to a lower optimal level of skills.

Figure 2

What happened in the 1970s?

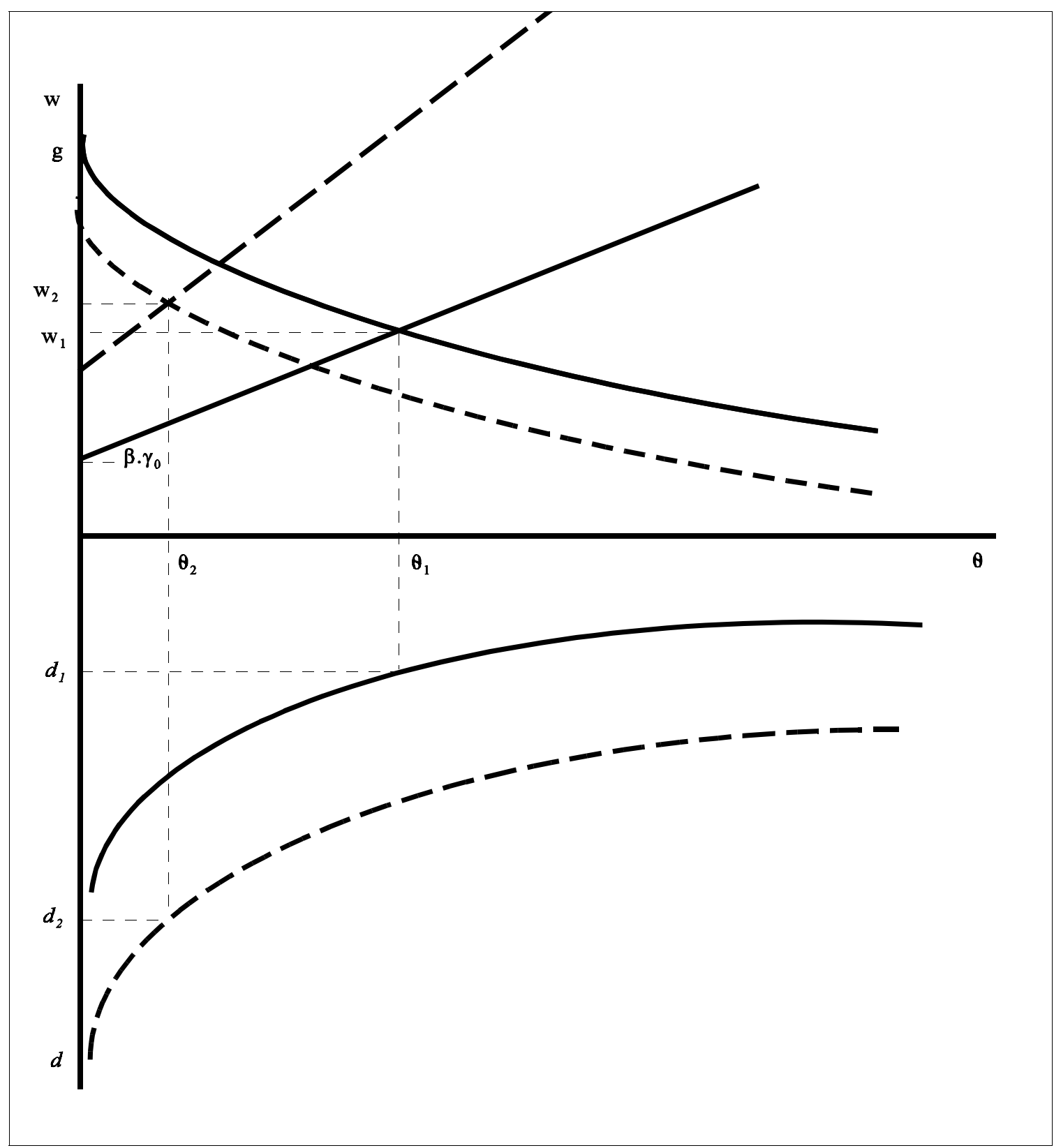


Also an important reservation should be made with regard to the analysis above, for not all workers faced a decline in search duration during the 1980s and 1990s. If search duration would have fallen to the levels of the 1960s and early 1970s, unemployment levels should be down too. This is not what we observe in the contemporary Dutch labour market. Only high-skilled workers have faced a dramatic fall in search duration and unemployment in the second half of the 1990s, which was mainly due to an upturn in the economy in favour of high-skilled workers. This notion of skill-biased technical change has reduced the demand for low-skilled workers relative to highskilled workers; particularly in the R\&D-intensive and rapidly expanding sectors of the Dutch economy - cf. Bruinshoofd and Ter Weel (1998) for a recent empirical analysis.

In addition, hysteresis in unemployment - in particular in the low-skilled sector - should be taken into account. As explained in e.g. Lindbeck and Snower (1986), it can be acknowledged that long-term unemployed workers are not included in the (Nash) bargaining process of wage determination. Thus wages are set so that involuntary unemployment remains (and becomes long-term), but the unemployed are nevertheless unable to improve their position through underbidding. These latter notions are not included in our present analysis. Nonetheless, our analysis highlights some aspects of skill formation and the matching process that enable us to explain the stylised facts mentioned above.

\section{The Stylised Facts}

In the introduction we presented four related stylised facts, which we have elaborated on in our analysis. First, we have shown that the returns to schooling have declined strongly over time which is in line with our first observation. Our intuition was that nowadays people invest in schooling not only to obtain higher wages but also to get a decent job. In our framework we have shown that this statement could plausibly be modelled and explained by taking into account both supply and demand side characteristics of the labour market.

Secondly, the general level of overeducation is explained. Not only are individuals who cannot become employed in the skilled sector overeducated, also workers in the skilled sector turn out 
to be overeducated. This can be explained in line with our first findings that the investment decision is not merely taken to maximise life-time income, as would be the outcome of human capital theory.

Thirdly, we have shown that unemployment for low educated persons is much higher than for high educated persons. Skilled individuals who cannot get a job in the skilled sector are by definition employed in the unskilled sector. This means that the general tendency towards overeducation - and therefore an increase in the amount of skilled labour supplied - leads to a further deterioration of the labour-market position of unskilled labour, which among others leads to crowding out.

Finally, the statement that the rate of return on overeducation is positive can be observed from the skilled labour market. In the analysis above, we have shown that this holds for the worker with an ability higher than the marginal ability. 


\section{Concluding Remarks}

This paper is a contribution to economic theory to the extent that it provides a systematic approach to incorporate several labour-market theories into one model. In addition, the model is able to explain several observations from the Dutch economy which could so-far not be explained by the existing models.

Building a theoretical framework along the search-theoretic lines of Pissarides (1990) and extending this model with human capital, labour queue and screening theory, we have been able to explain four stylised facts. First we have provided a solid basis for the paradox that the returns to schooling have declined strongly while attainment remained the same. Our explanation is that individuals prefer to invest in schooling not only to maximise their life-time income (human capital theory) but to increase the chance (search theory) that they will obtain a proper job (job competition and screening theory). Combining these approaches we can rather straightforward explain the general level of overeducation. In addition, it is clear from our analysis that the returns to overschooling are lower than the returns to the required level of schooling, but still positive.

In line with the observation that a general level of overschooling is prevalent in the Netherlands, we are able to explain that low-skilled workers have more difficulties in finding a job than their high-skilled colleagues. Since there are only a limited number of jobs, individuals who embody higher levels of human capital are in front of the labour queue, give the right signals to employers, and have therefore the best chance to become employed. Hence, low-skilled individuals observe higher unemployment rates. This phenomenon is made stronger by the fact that high-skilled workers who cannot obtain a job in the high-skilled sector will be employed in the low-skilled sector, thereby crowding out low-skilled workers. 


\section{Literature}

Becker, G.S. (1962). "Investment in Human Capital: A Theoretical Analysis." Journal of Political Economy, vol. 70, no. 1, pp. 9-49.

Beer, P. d. (1996). "Laag Opgeleiden: Minder Kans op een Baan, meer Kans op Ontslag." Economisch Statistische Berichten, 06-11-1996, pp. 908-912.

Blanchard, O. J. and P. A. Diamond (1990). "The Aggregate Matching Function.” NBER Working Paper 4000, Cambridge MA.

Bruinshoofd, W.A. and B.J. Ter Weel (1998). "Skill-Biased Technical Change: On Technology and Wages in the Netherlands." MERIT Research Memorandum 2/98-024.

Burdett, K. and E. Smith (1996). Education and Matching Externalities. Acquiring Skills. Market Failures, Their Symptoms and Policy Responses. A. S. Booth and D. J. Snower. Cambridge MA, Cambridge University Press, pp. 63-80.

Eijs, P. v. and H. Heijke (1996). The Relation between the Wage, Job-related Training and the Quality of the Match between Occupations and Types of Education. Maastricht, ROA.

van der Geest, L. (1995). "De Neergang van de Vakbeweging." Economisch Statistische Berichten, 23-08-1995, pp. 729.

Gelderblom, A. and J. d. Koning (1994). “Leren: Batig Investeren?” Den Haag, OSA.

Gelderblom, A., J. d. Koning and J. Odink (1997). "Loont Studeren?" Economisch Statistische Berichten, 18-06-1997, pp. 500-504.

Gottschalk (1997). "Inequality, Income Growth, and Mobility: The Basic Facts", Journal of Economic Perspectives, Spring 1997, vol. 11, no. 2, pp. 21-40.

Goux, D. and E. Maurin (1996), Changes in the Demand for Labour in France, STI Review, No. 18, OECD Paris.

Groeneveld, S. (1996), "Het Meten van Overscholing.” Economisch Statistische Berichten, 0506-1996, pp. 511.

Groot, W. and H. Maassen van den Brink (1996). "Overscholing en Verdringing op de Arbeidsmarkt.” Economisch Statistische Berichten, vol., no. pp. 74-77.

Groot, L. and A. Hoek (1997). Job Competition in the Dutch Labour Market. LOWER, London.

Hartog, J. (1997). On Returns to Education: Wandering along the Hills of ORU land. (AEA), Maastricht, MacMillan. 
Hollanders, H. en B.J. Ter Weel (1998). "Skill-Biased Technological Change in an Endogenous Growth Model." MERIT Research Memorandum 2/98-019.

Howell, D.R. and E.N. Wolff (1991), "Trends in the Growth and Distribution of Skills in the US Workplace 1960-1985.” Industrial and Labour Relations, vol. 44, no. 3, pp. 186-219.

Kettunen, J. (1994). "The Effects of Education on the Duration of Unemployment." Labour, vol. 8, no. 2, pp. 331-352.

Kleinknecht, A. (1996). "Potverteren met Loonmatiging en Flexibilisering." Economisch Statistische Berichten, 21-08-1996, pp. 622-625.

Koeman, J. (1996). "Loonmatiging en Macro-Economie.” Economisch Statistische Berichten, 21-08-1996. 692-693.

Layard R., S. J. Nickell and R. Jackman (1991). Unemployment. New York, Oxford University Press.

van Lede, C. J. A. (1995). “Werk Boven Inkomen: Wensdroom of Werkelijkheid?” Economisch Statistische Berichten, 04-10-1995, pp. 876-880.

Lever, M. H. C. (1995). “Cao's en Werkgelegenheid.” Economisch Statistische Berichten, 29-031995, pp. 300-303.

Linbeck, A. and D.J. Snower (1986). "Wage Setting, Unemployment, and Insider-Outsider Relations." American Economic Review, vol. 76, no,. 2, AEA Papers and Proceedings, pp. 235-239.

Muyksen, J. (1989). "Classification of Unemployment: Analytical and Policy Relevance" De Economist, vol. 137, no. 4, pp. 397-424.

Muyksen, J. and C. de Neubourg (eds.) (1989). Unemployment in Europe, MacMillan, London.

OECD (1998), Employment Outlook, OECD Paris.

Oosterbeek, H. and D. Webbink (1996). "Over Scholing, Overscholing en Inkomen." Economisch Statistische Berichten, 13-03-1996, pp. 240-241.

Phelps, E. S. (1994). Structural Slumps. Cambridge MA, Harvard University Press.

Pissarides, C. A. (1979). "Job Matching with State Employment Agencies and Random Search." Economic Journal, vol. 89, no. 3, pp. 818-833.

Pissarides, C. A. (1990). Equilibrium Unemployment Theory. Cambridge, MA, Basil Blackwell Ltd. 
Romer. D. (1996). Macroeconomics. McGraw-Hill, New York.

Schultz, T. W. (1961). "Investment in Human Capital." American Economic Review, vol. 51, no. 1, pp. $1-17$.

Spence, A.M. (1973). “Job Market Signaling.” Quarterly Journal of Economics, vol.87, no. 3, pp. 355-74.

Thurow, L. C. (1975). Generating Inequality. Basic Books, New York.

Thurow, L. C. (1979). A Job Competition model, in: Priore (ed) Unemployment and Inflation: Institutionalist and Structuralist views, White Plains, New York: 17-32.

Topel, R. H. (1997). "Factor Proportions and Relative Wages." Journal of Economic Perspectives, vol. 11, no. 2, pp. 55-74.

Van Ours, J. C. (1991). "The Efficiency of the Dutch Labour Market in Matching Unemployment and Vacancies." De Economist, vol.139, no. 3, pp. 358-378.

Van Ours, J. C. (1995). "An Empirical Note on Employed and Unemployed Job Search." Economics Letters, vol. 49, no. 4, pp. 447-452.

Van Ours, J. C. and G. Ridder (1995). "Job Matching and Job Competition: Are Lower Educated Workers at the Back of Job Queues?" European Economic Review, vol. 39, no. 9, pp. 1717-1731.

Van Smoorenburg, M. en R. Van der Velden (1995). Schoolverlaters Tussen Onderwijs en Arbeidsmarkt, ROA.

Webbink, D. (1996). Arbeidsmarktverwachtingen en Opleidingskeuze. ROA 10, Maastricht, Avessbury.

Weiss, A. (1995). "Human Capital vs. Signalling Explanations of Wages.” Journal of Economic Perspectives, vol. 9, no. 4, pp. 133-154.

Zon, A. van, J. Muysken, H. Meijers (1998), Assymetric Skill Substitution, Labour Market Flexibility, and the Allocation of Qualifications, in: H. Heijke and L. Borghans (Eds.), Towards a Transparent Labour Market for Educational Decisions, Avebury Publishers, London. 